\section{Response to: 'Correspondence on 'Long-term outcome of a randomised controlled trial comparing tacrolimus with mycophenolate mofetil as induction therapy for active lupus nephritis" by Xu}

I would like to thank $\mathrm{Dr} \mathrm{Xu}^{1}$ for his interest in our lupus nephritis (LN) randomised controlled trial. ${ }^{2}$ Although $28 \%$ of the recruited patients were ever positive for the antiphospholipid (aPL) antibodies at study entry, only four (2.7\%) of them had history of thromboembolism and two times positivity of the aPL antibodies that qualified the consensus criteria for the antiphospholipid antibody syndrome (APS). ${ }^{3}$ Four more patients developed the APS on follow-up, giving rise to an overall prevalence of $5.3 \%$, which is consistent with the figure reported in our entire cohort of systemic lupus erythematosus. ${ }^{4}$ Only one patient with APS at entry developed new onset hypertension after induction therapy with tacrolimus. The posterior reversible encephalopathy syndrome (PRES) was not observed in any of the tacrolimus-treated patients.

Thrombotic microangiopathy (TMA) in kidney biopsy is a well-recognised poor prognostic feature of LN. Factors associated with TMA include the APS, thrombotic thrombocytopenic purpura and chronic use of the calcineurin inhibitors (CNIs). ${ }^{5}$ Renal insufficiency, pre-existing hypertension, high lupus activity and the use of heavy immunosuppression that include high-dose glucocorticoids, cyclophosphamide, mycophenolate mofetil, CNIs and rituximab have been linked to the PRES, which occurred in $<2 \%$ of Asian patients with SLE. ${ }^{6-9}$ While the contribution of each of these factors cannot be easily differentiated, an inflammatory mechanism is increasingly suggested for the endothelial dysfunction in the PRES. ${ }^{7}$ Although there is no evidence to indicate that the CNIs are contraindicated in APS patients, blood pressure, renal function, electrolytes and neurological symptoms should be closely monitored in users of this class of drugs. The APS or the presence of the aPL antibodies were not in the exclusion criteria of the voclosporin study mentioned by $\mathrm{Dr} \mathrm{Xu} .{ }^{10}$ In view of the paucity of data in the literature, the prognostic value of TMA and its interaction with other risk factors in LN should be further explored in Chinese patients.

\section{Chi Chiu Mok 우}

Correspondence to Dr Chi Chiu Mok, Department of Medicine and Geriatrics, Tuen Mun Hospital, Hong Kong, China; ccmok2005@yahoo.com

Handling editor Josef S Smolen

Contributors I am the sole author of this reply letter.
Funding The author has not declared a specific grant for this research from any funding agency in the public, commercial or not-for-profit sectors.

Competing interests None declared.

Patient and public involvement Patients and/or the public were not involved in the design, or conduct, or reporting, or dissemination plans of this research.

Patient consent for publication Not required.

Provenance and peer review Commissioned; internally peer reviewed. (c) Author(s) (or their employer(s)) 2020. No commercial re-use. See rights and permissions. Published by BMJ.

\section{Check for updates}

To cite Mok CC. Ann Rheum Dis Epub ahead of print: [please include Day Month Year]. doi:10.1136/annrheumdis-2020-219087

Received 17 September 2020

Accepted 18 September 2020

\section{S Linked}

http://dx.doi.org/10.1136/annrheumdis-2020-219056

Ann Rheum Dis 2020:0:1. doi:10.1136/annrheumdis-2020-219087

ORCID iD

Chi Chiu Mok http://orcid.org/0000-0003-3696-1228

\section{REFERENCES}

1 Xu C. Correspondence on 'Long-Term outcome of a randomised controlled trial comparing tacrolimus with mycophenolate mofetil as induction therapy for active lupus nephritis'. Ann Rheum Dis 2020. doi: 10.1136/annrheumdis-2020-219056.

2 Mok CC, Ho LY, Ying SKY, et al. Long-Term outcome of a randomised controlled trial comparing tacrolimus with mycophenolate mofetil as induction therapy for active lupus nephritis. Ann Rheum Dis 2020;79:1070-6.

3 Miyakis S, Lockshin MD, Atsumi T, et al. International consensus statement on an update of the classification criteria for definite antiphospholipid syndrome (APS). J Thromb Haemost 2006:4:295-306.

4 Mok CC, Chan PT, Ho LY, et al. Prevalence of the antiphospholipid syndrome and its effect on survival in 679 Chinese patients with systemic lupus erythematosus: a cohort study. Medicine 2013;92:217-22.

5 Kotzen ES, Roy S, Jain K. Antiphospholipid syndrome nephropathy and other thrombotic microangiopathies among patients with systemic lupus erythematosus. Adv Chronic Kidney Dis 2019;26:376-86.

6 Jung SM, Moon S-J, Kwok S-K, et al. Posterior reversible encephalopathy syndrome in Korean patients with systemic lupus erythematosus: risk factors and clinical outcome. Lupus 2013:22:885-91.

7 Ho CM, Mok CC. Posterior reversible encephalopathy syndrome as a neuropsychiatric manifestation of systemic lupus erythematosus. Hong Kong Med J 2019:25:410-2.

8 Lai C-C, Chen W-S, Chang Y-S, et al. Clinical features and outcomes of posterior reversible encephalopathy syndrome in patients with systemic lupus erythematosus. Arthritis Care Res 2013:65:1766-74.

9 Damrongpipatkul U, Oranratanachai K, Kasitanon N, et al. Clinical features, outcome, and associated factors for posterior reversible encephalopathy in Thai patients with systemic lupus erythematosus: a case-control study. Clin Rheumatol 2018;37:691-702.

10 Rovin BH, Solomons N, Pendergraft WF, et al. A randomized, controlled doubleblind study comparing the efficacy and safety of dose-ranging voclosporin with placebo in achieving remission in patients with active lupus nephritis. Kidney Int 2019;95:219-31. 